\title{
The Public Administration Viewed from the Reflective Public Servants
}

\author{
Mirko Pečarič ${ }^{1}$ \\ ${ }^{1}$ University of Ljubljana, Faculty of Administration, Slovenia \\ Correspondence: Mirko Pečarič, University of Ljubljana, Faculty of Administration, Slovenia, Gosarjeva ulica 5, \\ SI-1000 Ljubljana, Slovenia. Tel: 386-1-580-5567. E-mail: mirko.pecaric@fu.uni-lj.si
}

\author{
Received: October 12, 2013 Accepted: October 21, 2013 Online Published: October 30, 2013 \\ doi:10.5539/par.v2n2p250 URL: http://dx.doi.org/10.5539/par.v2n2p250
}

\begin{abstract}
Public objectives are mostly implemented within the public administration. Despite Weber's idea of rationality in the public administration the latter operates more in evolutionary manner by imitation of processes that have been effective in other areas. A starting point towards taming today's complexity can be an individual who operates primarily from his/her personal characteristics, regardless of the existing theories about the public administration (PA) in a manner "think globally, act locally". As long as we do not clearly know how cognitive processes affect the functioning of an individual, the subjective concepts of decision making and the European Qualifications Framework (EQF) can be helpful, due to known levels of knowledge, skills and competences. Entering into the unknown with the full personal preparedness for changes will be the motto of the future PA. This motto is covered within the EQF's levels from 6 to 8.
\end{abstract}

Keywords: public administration values, efficiency, legal rules, complexity, human mind

Ethical Government means much more than laws. It is a spirit, an imbued code of conduct, an ethos. It is a climate in which... some conduct is instinctively sensed as correct and other conduct as being beyond acceptance (President's Commission on Federal Ethics Law Reform, 1989).

\section{Introduction}

How come that the science of PA supposed to be interdisciplinary, while states primarily look at the public problems through regulation? (Note 1) There are many works about the human resource management, ethics, values, psycho- and socio- logical elements in the PA, but when comes to a "public situation crisis" the legislative and executive branch usually respond to it with a new legal arrangement that should "cure all evils of the past". Regulators then hope with a new set of rules - that is based on past situations and examples - to catch also the future ones (as the future would be some kind of the past's duplicate). For the future events we need forward, not backward look; we drive a car looking mainly through the car's front window not by the rear-view mirror. A legal state is not legitimate because of many rules for almost every occasion; (Note 2) they are only one of many means by which states strive to achieve their goals. Prior to creation of rules there are the peoples' needs, desires and their intentions, so detection of a problem as the problem and its apparent solution lies outside regulations; the latter are only final results of something else. This "something else" can be seen also in the importance of good (Note 3) and better management (Note 4) in the public administration. With the expansion of public tasks, with a larger degree of complexity that arises from every new relation, action, cooperation, or absence of them (content is becoming more complex with every new position or assignment: with only two possible states input variety is $2^{\mathrm{n}}$, while output variety is already $2^{2 \mathrm{n}}$ and connections between things are $\left.n[n-1] / 2\right)$, good or better is because of its flexibility still on the pedestal of public importance. The notion of "good" has been present for many centuries and means something rational and moral. While it is directly connected with the office, (Note 5) legitimacy (Note 6) or - not only utilitarian (Note 7) - mode of thinking, (Note 8) this paper will argue that goodness is primarily connected with individual's com-passion for others.

The public servants as the drafts chief providers - by this they could also be viewed as the informal people's representatives - have to anticipate how the people will reason and feel in the future about some decision or action. For a draftsman of state operations a starting point is therefore the prediction and evaluation of what would be reasonable and acceptable for the people; by doing this, there is also present non-stop tension and the mixture of 
ethos, mind-set, ethical government and the law, legal process, reasoning and substance, openness and closeness. This paper starts from the assumption that public servants can be viewed not only as draftsmen, but also as the samples of nation's rationality and morality. (Note 9) Even with this assumption we cannot fully eliminate a gap between objectivity and subjectivity, a gap of what constitutes an objective fact by the subjective mind (of a public servant) that has been as the moderate realism summarised already by St. Thomas Aquinas, (Note 10) because we still do not really know how they - as the public servants - think.

While the systematic, objective and organisational elements are deeply intertwined with the subjective elements, we will give - according to the moderate realism of St. Thomas Aquinas - more emphasis on the latter elements. Difficulty (or freedom) of this basic notion is in its inability of being put in the legal frameworks that would be applicable for all future events. Can therefore an official's skilful cross-examination of predispositions that pre-administer later decisions be more efficiently revealed? Why are the "bureau pathologies" constantly assigned mainly to the PA, in which personnel structure constantly changes and in which people comes also from the (apparently more efficient) private sector (who later in their conduct usually become similar to the rest of the public servants)? Have the past failures occurred, because of the lack of systematic dealings (if failures occur regardless from where people come into the PA - is it something wrong with the PA's organisation?) or they can be more specifically attributed to the subjective failures of people and officials, because of the lack of deeper subjective understanding of our own decisions? Why despite of so many scientific articles and books, statistics, its statistical correlations and other research methods we still do not know enough about ourselves? It seems that the key role in the PA - as in all other activities - is still, as it always was, in each individual, who through his subjective mind contributes to (public) decisions. (Note 11) And the latter are inevitably more or less distant from the classic causal link that is framed in the analogy and mechanistic causality. (Note 12) The focus of this paper is the assessment of some theories that could affect the human and/or subjective side of personality within the PA; following the analysis and synthesis of the discussed approaches, the paper will put examples of the potentially useful application of subjective concepts. They are taken from the theories with subjective elements and from the transparency and transferability of competences within the field of lifelong learning. On this basis at the end of the paper the recommendations for the future research will be given.

\section{The Public Administration in Search for the Holy Grail of "Flexible Stability"}

Every theory from the field of the PA wants to establish a new balance between the peoples' rights and governmental efficiency, while in every one of them can be spotted some unintended consequences. Already Wilson in 1887 claimed that '[i]n government, as in virtue, the hardest of things is to make progress' (1887: p. 207), which he put at the first place in the PA. (Note 13) If we limit only from the NPM onwards, we now see that freedom from regulation and the more flexible PA supposed to be the NPM's solution, but the NPM's assumptions about three Ms' (markets, managers and measurement) 'led to the destabilisation of the organisational characteristics of public service and the destruction of the ethos which underpinned them' (O'Toole, 2006: p. 6). In addition to contributing to an increasingly hollow state, NPM's philosophy and practices have contributed also to the thinning of administrative institutions. (Note 14) NPM is based on "letting the managers manage" (Norman, 2001), while public servants as the main draftsmen were left aside; independent agencies presupposed - in accordance with the public choice theory - that better and more professional people are outside the PA, but they at the same time gave blow to the traditional administrative values of legality, impartiality, and independency. De-institutionalisation and de-professionalization of the public servants are shown also in their diminishing personal initiative. The multi-sector workforce has had not only implications on the public service delivery, but also on relations between officials themselves, on relations with citizens, users and their established practices. We took the NPM only as an example that will in each case give similar results, because the end is constantly re-built with every new relation or iteration.

Recent development of new ideas that deal with the PA and to it related tendencies for greater political and legal management and control have embraced also the network elements, which had led to different notions that supposed to be prevailing in the PA. (Note 15) One of the "nicest" or to the people most pleasing could be the public value theory, because of its democratic and/or participative elements, that take into account individual and public preferences, multiple objectives and means to achieve accountability (see Kelly et al., 2002). (Note 16) It is somehow surprisingly that even lawyers lately recognise a need for the public administration theory to better describe administrative law. (Note 17) Due to the apparent ineffectiveness and inefficiency (that can be also a consequence of so-called Veblen's trained incapacity that is in the PA known as Weberian rationality) in the PAs have been launched different regulatory methods (the cost-benefit analysis, regulatory impact analysis and their variants), but their focus cannot give a complete picture, because they have not been connected with the relevant situations (experimentation), nor with the subjective elements that are present in regulated fields. This picture 
cannot per se be complete neither with the enlargement of place and space (to the EU and to the present international agreements, organisations, international courts, and informal clubs, like G7, G8, G20 or the Basel Committee on Banking Supervision). There is obviously still 'a strongly felt need to change bureaucracy' (Frederickson, 1996: p. 263) that takes place also on a more and more global, interconnected level outside the national borders. Meier argues that 'problems in [not only in American] government are not problems of bureaucracy but problems of governance [the process of governing society in a generic sense]' (1997: p. 194); governance ought better describe de facto situations, because it is based on a holistic approach:

both PA and the NPM fail to capture the complex reality of the design, delivery and management of public services in the twenty-first century [...] there is a pressing need now for a more sophisticated understanding of public policy implementation and public services delivery - one that moves beyond the sterile dichotomy of "administration versus management" and that allows more comprehensive and integrated approach to the study and practice of public policy implementation and public services delivery (Osborne, 2010: p. 5).

The above-mentioned theories gave a new, wider look on the complex environment and more sophisticated understanding of public policies, but as the past PA's theories they are still mainly focused on the organisational questions (Note 18) or more specifically - they describe what is going on (right now in specific field), but not why is that so. If we would proceed on this path, our notions would be changed according to every new circumstance, but we would be still only describing and not administrating them - only with re-organisation, re-naming, re-placing of competences and tasks, with downsizing, re-regulation, etc., the main goal of achieving objectives cannot be fulfilled. The combination of details may give quite a unique and characteristic image of the whole society; it is also the basis for Pollitt's contextual approach (Note 19) (where right answer does not exist in advance, because each situation demands specific answer and combination of data that do not depend only on information, but also on collection of information and its evaluation) that can be in the closest proximity to the core of public operations. Solutions seem to change in accord with changes in the environment or situations of a particular state, but also this approach can only better describe a factual state, while facts would still depend on something else.

Despite the initial enthusiasm in the newly emerged, above-mentioned theories, practice constantly shows that the world is more complex, flexible, and unknown than we think. All of these (organisational and legal) ideas are mostly about adjustments to the present situation, while they are not addressing the process of adaptation itself. Theories of the PA "suffer" with the same disease as it is present in the law - they are trying to describe past events that suppose to be relevant also in the future. A wider view on situations shows that ideas are generated and shaped in accordance with the existing reality, current practice, and institutions; usually we start from what we want and believe as the main point, from which we interpret law, best organisational models and the like. We still in general guess or follow others in a la black box style without knowing why they had done something in a particular way. We know for a long time that "a sense of moral judgement and a distinction of "right and wrong, good and bad" are cultural universals' (Brown, 1991), but what is the right or desirable quality (as the meaning of good) depends from its evaluator (all the above mentioned theories have been created by their singular authors). We should go therefore back to an individual who is aware of his/her mentality.

\subsection{Adaptation as the Subjective Element of Recognition to Adapt}

All situational circumstances are inevitably connected with the subjective ones. Humans adapt and control their behaviour because of multitude of senses or receptors. In natural systems a function of control (because of multitude of receptors) is placed throughout the system. (Note 20) If the system responds to stimulus, than we can say that it is aware. Awareness is present only when we (re)act. We are aware because we recognise something as recognisable; our senses and ability to learn and/or predict what will probably happen, if similar elements will be present in the future, are very important.

Everything around us is connected with the world as we see it: our capacity to reflect is not shared by other animals. From this premise we can proceed to the human mind as the main "regulator with multiple feedback loops". This subjective element has been mostly neglected in the law and the PA - although they both demand impartiality, the absence of any conflict of interest, competences and professionalism, these elements were present already in $19^{\text {th }}$ century; the human mind should be more carefully evaluated as the first point, from which we build our decisions, regardless of organisational structures of public institutions. We should be foremost aware of: who detects information, how, when, where, why, and what are alternatives and consequences. All system-oriented findings are based on basic human characteristics of persons, who are in the system and who define predispositions for system and for other people. At the core of the PA are psychological characteristics and philosophical beliefs of public servants; we could also say that ethics is in its core. (Note 21) The industrial age emphasised the machine that radically multiplied the muscle power of man, but not the right-brain mental power of humankind. Lynch \& 
Lynch (2006) propose an alternative approach for the 21 st century by using a virtues-based approach to the world ethics, combined with the common spiritual wisdom found in the world's major religious traditions (Hindu, Jewish, Buddhist, Christian, and Islam).

The PA will be adapted as it will be its public servants: they will be adaptable only if they regard their values and virtues along other people's rights and obligations, i.e. if they will use their ethics (virtues) to become - because of proximity to other humans that enables the public servants to feel with them also - morality (values). If they will not recognise differences, neither the PA will be adaptive or responsive. Difficulty behind this is in what has taught already Cicero: 'the most important thing in your life is to become a virtuous person and so to live and act in a morally worthy way; but you can only achieve this for yourself ... No book can give you the answers in advance' (Annas, 2004: p. xx, emphasis added). (Note 22) Dworkin defends the unity of value, because 'the truth about living well [how to live well - ethics] and being good [how we must treat other people - morality] is mutually supporting: what we think about any one of these must stand up, eventually, to any argument we find compelling about the rest' (2011: p. 1).

With the above-mentioned text it was shown that complexity cannot be tamed only through non-stop ex post search of circumstances for the best ex ante solutions, but also through the understanding of our inner self. We should be the starting point as persons (the mind) and as organisation (the body) with multitude (and parallel) connections. Given the differences in situations and blurred boundaries, there is no uniform organizational structure and leadership style that would be highly effective in all types of companies and institutions; the best legal order or one-fit-all model do not exist for everybody and everyone. A place for the PA can be everywhere, if we recognise it as the most appropriate for $u s$, if we recognise the public interest in it. We can be adaptable only if we are adaptable. Only by this way we can be stable in different circumstances. Are the natural uncertainties and our personal recognition of this the main path in search for the "holy Grail" of the PA? While the former are beyond our reach, the latter can be enlightened.

\section{Hidden Subjectivity in the Theory of Public Administration}

Humans are the source of human reality and the same applies for the PA; as the latter is the biggest entity in a government structure the first are not only important, but evidently the most important factor in the administration of state. As the public servants provide information for politicians in majority of cases, they can represent some form of a feedback loop (Note 23) and by this also a badly needed factor for administration of state. Is the internal, subjective perspective of individual public servant firstly to be understood, if we want to understand the PA or governance at large? Already the Northcote and Travelyan Report (1854) dealt with the perception of the immeasurable carelessness and lack of responsiveness in the quality of public services. The same Report spoke also about the moral character or moral fitness of candidates for public service, where 'the keenest emulation would prevail among those who entered it [in the permanent civil service] and... were endowed with superior qualifications that would rapidly rise to distinction and public eminence' (1854: p. 4). (Note 24) Efficiency of the public service was then related as much to the people's moral qualities as to their abilities, while the later modes of governance left them aside. Will PAs have to re-discover human virtues and values, (Note 25) will they have to re-discover humanity? (Note 26)

We do not deny that existing theories also embrace human factor inside/outside of the PA: hope in better performance, mutual and self control, increasing feeling or awareness of personal duty in contributing and participating in solving major public problems have been present in different movements before (in the New Public Administration - NPA) and along the NPM, from the 1970s onwards. They wanted to install re-generated, self-referential, self-renewing, democratic public culture (Note 27) (from NPA's conception of the citizenship, which entailed 'a vision of the informed, active citizen participating "beyond the ballot box" in a range of public activities with both elected and appointed public servants' [Frederickson, 1996: p. 265]), which depends on individuals or civil society and continues the legacy of NPA in the newly established notions of administrative justice, (Note 28) meta-governance, and e-governance. In the latter, awareness is clearly present that IT cannot solve the problems without dynamic human makers. (Note 29)

Institutions do not form decisions as an independent force - individuals make them. It is no wonder that after the NPM emerged Denhardt's theory of Public Service in which 'the primary role of the public servant is to help citizens articulate and meet their shared interests rather than to attempt to control or steer society' (2000: p. 594), or Moore's theory of Public Value, in which the arbiter of value is collective, acting through the representative government. (Note 30) Are we moving back to the base of everything: to human(ism) in the public administration, or at least to the NPA from the late 1960s? (Note 31) We still have not solved the fundamental dilemmas of the human mind and it seems that they will not be solved also in the near future; the human mind is probably 
constantly supplemented, changed, rearranged and correlated with other factors. Progress is in the fact that we are aware of its/our (hidden) strength, and in our constant attention (Note 32) to it. If a man has this strength by which he balances values embedded in him, it is probably irrelevant if he has power or status. Can therefore hidden subjectivity in the PA be found in balancing between different values, due to failure (or unsuccessfulness) of theories that are focused more on organisation? We will therefore proceed with some theories that are focused more on our subjectivity to see if there are present clearer elements of our awareness.

\section{Subjectivity as the Sine Qua Non of Public Administration}

Weberian neutrality of public servants was long ago abandoned by Waldo's quest for values, (Note 33) while in Mayo's human relations the previously abandoned idea of the faceless and anonymous bureaucrat was somehow forgotten in the public choice theory from the mid 1950s of the last century (Note 34) with works of Black, Buchanan, Tullock and Niskanen. At the same time we should not forget 'the limited ability to rely on introducing social change through the law when the law is not backed up by values' (Etzioni, 2004: p. 158); the moral voice is much more compatible with free choice than with state coercion. To Etzioni the shared values serve as a sort of framework and the glue of society, so the public officials have to rely on the values in their drafts for the new content of the public interest that is thereafter formally applied in every legal act or material operation. Values must be therefore visible in the notion of the public interest that is afterward present in legal operations of officials. How can be in such intertwined local, national, and global situations established clear guidelines for officials' operations with assumption that we should give more attention to the human factor? Boundaries are blurred between the state as an institution and Durkheim's state as officials. (Note 35) Pollitt and Bouckaert have made extensive research through the years, claiming that there are "several key concepts, including governance, networks, partnerships, "joining up", transparency, and trust; and no dominant model' (2011: p. 11, emphasis added) neither on the objective nor on the subjective side. The legal rules and principles are not the only norms that frame the PA; Cane's focus is on the bureaucratic values and their relations with the values that underpin administrative law, because 'fidelity to the norms of administrative law is certainly not all there is to good administration' (2011: p. 21).

An organization and people in it are the inseparable elements, and it is no wonder that this is also valid for the human side (as it is for the organization) in the contextual theory about representation: Groeneveld and Walle have developed it by 'looking at the context in which the PA operates' (2010: p. 240). They emphasise along the managerial approaches to the representative bureaucracy also the moral ones and underline the exemplary role of a state: 'the political viability of managerial and moral approaches needs to be taken into account through acknowledging political realities and existing distributions of power in society' (ibid: p. 256). Perry and Hondeghem see the key for success in the public service motivation (PSM) 'as an individual's orientation to delivering services to people with a purpose to do good for others and society' (2008: p. vii). This theory is the bridge between the officials' personal interests and the public interest. It refers to the process, in which individuals contribute through their work to the public good in a way that satisfies their personal needs that are similar to the public ones. It is about the motives that people have for their dedication, not because of the offered incentives (higher wages etc.) for their work. The motives depend on a case-by-case basis, upon personal, historical and situational factors. Public duties are not carried out (only) because of money, but for their own sake; they can combine pleasant with useful. The PSM must be grounded in the individual and not in the public institutions per se; there is a constant process of induction and deduction, reflection and the power of judgement (what is the best for public services and how to achieve them individually).

As the role of official in the pursuit of private, special, or collective interests is undetermined in the future, we cannot describe it only in the relation to his current motives and interests, but we can use Wittgenstein's approach to language in order to better understand bureaucracy: we have to take into account various ways in which bureaucracy operates. The substantive guidance for this causality can still be found in Aristotle's nature of things, i.e. in formal, material, moving, and final causes. (Note 36) From this wider substantial efficiency later emerged the narrow technical efficiency as a ratio between inputs and outputs that is not "efficient" enough. (Note 37) Human thoughts, emotions, and values are mixed in different manners. Nevertheless we can still indirectly influence them with our activity:

Because we always have control over our component of behaviour, there are also simultaneously - if we significantly change our behaviour - changed components of thinking and feeling and our physiology. The more we actively engage in the active behaviour [...] the more we will also revise our thoughts, feelings, and listen to what our body tells us. If this gives us greater control, there will also be better feelings, more pleasant thoughts, and physical comfort (Glasser, 1994: pp. 51-52). 
The first step to the clearer answer of what is going on in the PA is awareness that public officials must feel energy, which has also been the most important for Hamilton (Note 38) and Durkheim; (Note 39) only then we can reflect on the conditions for social intervention and the ways of its evaluation: "the implementation of the critique itself must be understood as constituting of the critique itself in the practice of intervention, in the form of know-how about how to engage in collective construction with the actors as they analyse their own positioning' (Lenoble and Maesschalck, 2010: p. 249). The public employees' behaviours have a big impact on what they and other people think, feel and behave; they have de facto big impact on the administrative implementation and political decision-making at all levels. Like the members of Parliament they are the representatives of the whole nation; the public employees represent emanations of the public interest that are many times prepared as predispositions, on which the members of Parliament afterward decide.

\subsection{Subjectivity in the Theory of the PA's Decision-Making Models}

Along the above mentioned theories that addressed subjectivity of the public servants, there are also theories that have a subjective focus on decision making. If we agree that also public servant have inner virtues and outer values, we are going beyond the politics-administration dichotomy. Simon e.g. wanted to install personal conditionality as "bounded rationality" between the means and ends, by determining the real organizational environment of decision making, where goals are accomplished only 'satisfactorily or good enough' (2000: p. 119). He thought that 'the behaviour of a rational person can be controlled ... if the value and factual premises upon which he bases his decisions are specified for him. This control can be complete or partial - all the premises can be specified, or some can be left to his discretion. Influence, then, is exercised through control over the premises of decision' (ibid: p. 308). (Note 40)

The public choice or the principal-agent theory at this point rightly draws attention to the individual's desire and private interest, but it points out the impossibility of covering the entire human mind merely with formally established values, regardless of the real ones. A relation between means and ends in the public decision-making is objectively and evolutionary closer to Lindblom's "muddling through", where 'the correct policy is made through comparison with other ones [... while] in situations where there is no agreement on values and objectives ... the test is on agreement on policy itself, which remains possible, even when agreement on values is not' (1959: p. 83). Etzioni supplemented Lindblom's incremental approach with his "mixed scanning" in which the most fundamental decisions are used together with incremental ones, because 'most incremental decisions specify or anticipate fundamental decisions; and cumulative value of the incremental decisions is greatly affected by the related fundamental decisions' (1967: p. 388). Such a mix is also close to Rohr's ethics of bureaucrats, in which orientation to the regime values can help bureaucrats in choosing their path, when law gives them no guidance, when they have to use their own discretion: [t]he oath to uphold the Constitution is the moral foundation of ethics for bureaucrats' (1989, p. 70). The case of regime values can be treated similarly, 'namely much more as a normative than as an empirical concept, referring to the values, not of any historical regime, but of the quintessential or simply the best regime' (Overeem, 2008: p. 15), as the latter is in the domain of each individual, while in similar vein the best public sector is in the domain of officials.

Although the above mentioned, more subjectively-focused theories gave valuable insights, they still do not show how decisions emerge, how are they really made and in what circumstances. Fukuyama in 2006 noted that 'the quality of a bureaucracy that is insulated from public scrutiny and oversight deteriorates over time; corruption can be reined in only if a broader public is made aware of its existence and demands better performance from public officials' (2006: p. 141), while now he no more speaks about quality per se and recognises that 'there is little agreement on what constitutes high-quality government' (2013); we can say also about what constitutes better performance. (Note 41) We still cannot measure what autonomy and capacity really are. But what we could gain, if we could establish that one state is e.g. 17, $2 \%$ higher in autonomy from the other one? While we de facto in our ordinary lives do not live according to statistics or percentages, there is no guarantee that with reducing or increasing of autonomy some state would be as efficient as it is the compared state. The law cannot solve all problems, because causes for our happiness, effectiveness, etc., are not in it. These theories indicate complexity in decision-making, but they cannot tackle it. What is therefore known about the concepts of decision-making that are at first established in our thoughts?

Public administration should increase its recognition of the deleterious effects of unconscious rhetoric in our language and way of thinking, of symbolic systems that are at work under the surface of public administration's consciousness. It should increase its appreciation for the relevance of psychoanalytic understandings, which are currently pursued on public administration's circumference. It should indulge the play of analysis (Farmer, 2010: p. 194). 
The still-uncovered future path could be foremost in subjective conditionality of human mind, which perceives conditions in surrounding nature as objective or subjective elements. All previous attempts to highlight subjective side of the public servants or their decision-making somehow merely scratched the surface. In the next subsection of this paper we will deal with some complex parts that could be the main predispositions for better understanding of decision making in the PA.

\subsection{Subjective Concepts of Decision Making}

For Lukacs 'what governs the world (and especially in the democratic age) is not the accumulation of money, or even of goods, but the accumulation of opinions' (2005: p. 45). For him 'our concern must be with how people think, how they choose to think, how they are influenced or impressed to think and speak' (ibid: p. 47). Weberian instrumental rationality 'sine ira et studio' (Weber, 1978: p. 125) cannot provide clear guidance for activities, where and when goals must be achieved that are in conflict with each other and which depend on the individual choices and balancing. Behind every situation is always a human who evaluates it and offers solutions. As everyday practice shows, there are irregularities despite the overall higher level of education in the public service than in past times. Although the work on HRM in the public service for the $21^{\text {st }}$ century speaks about "mindful", "mindset", or "solution-minded" civil service (Sistare et al., 2009), for which 'social equity and values are articulated in public laws, policies, and regulations' (Long-Green, 2009: p. 27), such stances are still incomplete: life is much more than the law, although the latter is its part. While in the law still prevails only "impartial and independent reason", " $[\mathrm{t}]$ here is no intrinsic opposition between emotion and reason: emotion is a principal source of motivation, focusing us toward particular goals; and it can direct great powers of thought on the goals it evokes' (Simon, 2000: p. 91). It seems that we are continuously dealing with the same questions for which no one knows answers; we all agree that we must be "good" - but how good, in what manner, to whom, with what or why?

The relation between public servants and citizens is psychologically complex and cannot be reduced only to the relation between rules and facts: human mind is the one that puts them together (a priori or a posteriori) as such. If we want to comprehend the PA, we must foremost understand the mind of a public servant. One of the best-known tools is the Myers-Briggs Type Indicator (it represents - based on Jung's theory of psychological type - a psychometric questionnaire designed to measure psychological preferences in how people perceive the world and make decisions [Myers \& Myers, 1980; 1995]), but some researchers have interpreted the reliability of the test as being low (Pittenger, 1993). We are still left with ideas, not being tested by the controlled scientific studies. But before we can approach to such studies, we must have concepts, from which we could build harder elements (like before gravity the concept of weight must have been established). We will highlight the concepts of: (I) apparent reasons, (II) a projection of evil, (III) positive orientation and (IV) relational satisfaction.

(I) People usually act without thinking, in a routine manner, many times only with an apparent reason of "because" (see Cialdini, 1998: pp. 5-6). Legal rules (sometimes) satisfy the principle of legal certainty and formally protect people from the conflict of values, rights, or obligations, but without context in which they were developed and implemented, there could not be a whole picture: no rule is self-interpreting (Wittgenstein), because 'only interpretation determines what is the correct application of rule' (Baker \& Hacker, 1988, p. 144), no choice is clearly guided only by certain rules (Boltanski \& Thévenot, 2006) and all social structures arise and are transformed by individuals that mandated them. The structure is more dynamic than it is conventionally assumed (Giddens \& Sewell, 1984), while the formation of structures is made by individuals' assumptions. (Note 42)

(II) One of the possible concepts could be Sartre's projection of evil: people hate in others that half of themselves, which they apparently reject. (Note 43) Because they cannot reach other people through emotions, they look at them as objects: 'my objective qualities that are recognized by them do not express what I am, but what I am in relation to them' (1981: p. 133). Thus, the objective definition of misbehaviour that people assign to others, the latter perceive as subjective; they let themselves be personally persuaded that this definition is related to their subjective and hidden part of being. By this way people adopt illicit desires of other people and internalize them as their own: 'the more we think that people are corrupt, the more people will be corrupt' (Rothstein, 2000: p. 479). The more people think that public administration is inefficient, the more it will be inefficient and the more probably the public servants will act so. Already in 1946 von Mises warned that such emotional statements of the general public (that were in general excuses for their personal inaction) (Note 44) are against the PA; the common stereotypes of the PA are pointing to its wastefulness and inefficiency. In such cases the minds of public servants can absorb such stereotypes as their own or they can vice versa negatively think about people as being e.g. too dependent, illiterate, unintelligent, ungrateful, or unjust. If the public opinion is too negative, then the PA will probably also not be too positive. (Note 45) 
(III) The human mind (or its orientation) must be positive; the same is valid for the progressive values of 'cooperation, knowledge, and openness to alternatives, economics as means rather than end, limited inequality, and Earth as a home to be protected' (Box, 2008: p. 22). Such values automatically trigger questions about mechanisms for initiating change that Box sees in the 'imagining alternative futures, scenarios that are different from the status quo' (ibid: p. 35), or Wainwright and Little in 'a deepening and strengthening of democracy and a reinvigoration of public service values [that] can be the most appropriate spur to real improvement in how public goods are provided' (2009: p. 13). Public servants and citizens must therefore regard each other in a positive manner, because human mind projects content into others as well as into itself.

(IV) Beside factors that focus our attention on the stated factual goals, we should pay also attention to the relational satisfaction that is affected by the way we perceive messages, get involved with other persons and by the way we evaluate past experiences, expectations, social roles, self-concepts, self-fulfilling prophecies (Note 46) (when we - at least unconsciously - wish a certain outcome to happen, our expectation of that outcome is heightened, because we unconsciously take actions that lead to that outcome) and a wider culture (habits), in which we live. 'What is needed in analysing the action of norms today, is not a focus on repression and suppression, but rather a focus on the power of relation with the external in the process of self-transformation undertaken by social subjects in order to emerge from reification' (Lenoble \& Maesschalck, 2010: p. 249). In spite of the contrastive (when a message is adverse to what we expect), repetitive messages, and messages with intense stimulus, we must not overlook the messages with low stimulus, single or few repetitions, and unexpected messages. It is not enough that legal procedures and reviewing mechanisms exist; they are focused on consequences and not on causes that have led to them. 'Laws and regulations are often ineffective guides for administrators trying to determine what to do. However trite this observation may seem, laws and regulations are better at telling administrators what not to do than what to do' (Fredericson, 2010: p. xiv).

What can the individual do, if he is aware of such conditions, aware of "what to do"? In the absence of the scientifically determined findings about the good administrative values, we can offer only the main subjective concepts to which attention must be focused in the future. They are the signalling behaviour, positive stance, the self-fulfilling prophecy, the principle of reciprocity, and relational satisfaction. We must be aware of them even in the case of low stimuli, because they affect the "good" or "bad" PA. Efficiency, effectiveness, professionalism, transparency, accountability, responsiveness, etc. are only apparent directions (or even words) by which officials conduct their work, if they do not internalize them as 'the quasi moral principles of their work' (Note 47) as their main guides.

\subsubsection{The European Qualifications Framework}

Within the subjective concepts could be used also the $\mathrm{EQF}$ 'as a translation device to make national qualifications more readable across Europe, promoting workers' and learners' mobility between countries and facilitating their lifelong learning' (European Commission, 2013). The EQF's learning outcomes (Note 48) can be used as outcomes that are expected also from the public servants and as results that confirm the presence of cognitive elements in learning (knowledge), skills (use of logical, intuitive and creative thinking) and competences (responsibility and autonomy). The EQF is divided into the eight-level framework where each level (Note 49) defines a set of descriptors as the generic outcomes. This framework can be used as a methodology by which the subjectivity of the person can be at least indirectly assed by the learning outcomes.

\section{Conclusion}

Life has always more in it than rules can show; Miles' law ('where you stand depends on where you sit' [Miles, 1978]) is applicable also in the PA. The PA cannot be objectively addressed within the mainly legally oriented theory of the PA; our evaluation shows that we have to look on the successes and failures of the PA also through the basic characteristics of the human mind, in which decisions depend on our predispositions (legal rules, rules of thumb, emotions, reason and/or everything what we know, feel or sense) by which we perceive the world around us. (Note 50) Awareness or a mind-set is more important than specific means or techniques. (Note 51) This paper gives reasons why there cannot be one best model that can be applied everywhere or in every occasion: there are not so many interests, as are many different views. To the specific management and institutional ideas (public choice, hierarchy, autonomy, centralisation, decentralisation, etc.) in the PA is given too big emphasis, but not to real context, which we evaluate as persons.

Re-introduction, deeper development and research of human characteristics in the science of administration have to be more focused on the official's human mind that is inevitably connected with the decision-making processes in public affairs. The future theory of public administration should include and test the basic findings that have been developed in psychology - especially when public power is used to coerce people (e.g. Zimbardo's or 
Milgram's experiment). The human mind is more complex than it can be understood from a certificate of good education or job specification. A reductionist approach cannot be used, if there does not exist a priori holistic, pluralistic whole. (Note 52) Public decisions are also dependent on the (non)legal, (ir)rational elements, on the real and potential threats or possibilities. Europe gives nowadays a big emphasis on the so-called " $21^{\text {st }}$ century or innovation skills" (Note 53' that are mainly the subjective elements which were discussed in this paper.

We would like to know for what, why, whom, what, and on what basis the PA actually governs, even if we do not know all answers to these questions. A mysterious formula of order is constantly present and absent at the same time; it is about the idea that we continually implement it - and sometimes really without seeing it - it is about combination of our innate, instinctive desire to see and to re-find order. Decisions by the majority of votes, analysis of costs and effects, regulatory impact analysis, and similar models of decision-making are at the present level still a pale approximation of the processes that constantly operate in our mind. We do not know enough about the public servants' minds that create the content of administrative values. More research will be needed about (apparent reasons, a projection of evil, positive orientation and relational satisfaction) and other personal elements (e.g. subordination, honour, respect, loyalty, modelling behaviour) that are present in the PA's decision making. Given the lack of satisfactory or only partially satisfactory answers from the analysis of the existing theories of our subjectivity, the paper urges for the additional psychological research. Only by this way good-, sound- and/or caring, cautious (administration, governance) and other notions of the PA can be properly assessed. In the meantime the discussed four subjective concepts (predispositions) and the EQF (outputs) with the clear focus on human mind and on knowledge, skills and competences, irrespective of the routes of acquisition (by the law, morality, culture etc.), can be the helpful tool for evaluation of our decisions.

In us it is always more personal note of freedom, security, and survival than we can deduce from the legal books. We must 'actually put ourselves in context and consider the potential conflict of our time' (Unger, 2004: p. lv) regardless of the existing theories. They were established in a different time and in (at least slightly) different conditions. They are not a magic formula. The magic is in us, in you. Look around, search inside you and see for yourself. Then (locally) step into the world's (global) "shoes" - there could be a universal basis of our humanity.

\section{References}

AJCT. (2010). Principles for Administrative Justice. Retrieved from http://www.justice.gov.uk/ajtc/docs/principles_web.pdf

Althusser, L., \& Balibar, É. (1970). Reading Capital. London: New Left Books.

ATC21S. (2013). What Are 21st-Century Skills? Retrieved July 28, 2013, from http://atc21s.org/index.php/about/what-are-21st-century-skills/

Annas, J. (Ed.). (2004). Cicero: On Moral Ends. Cambridge: Cambridge University Press.

Baker, P. G., \& Hacker M. S. (1988). Wittgenstein: rules, grammar and necessity. Wiley-Blackwell.

Beer, S. (1972). Brain of the Firm. New York: Herder and Herder.

Black, D. (1948). On the Rationale of Group Decision-making. Journal of Political Economy, 56, 23-34. http://dx.doi.org/10.1086/256633

Boltanski, L., \& Thevenot, L. (2006). On Justification: Economies of Worth. Princeton Univeristy Press.

Box, C. R. (2008). Making a Difference. Progressive Values in Public Administration. New York: M.E. Sharpe.

Brown, D. E. (1991). Human universals. New York: McGraw-Hill.

Brown, B., \& Stillman, R. J. (1986). A Search for Public Administration: The Ideas and Career of Dwight Waldo. College Station, TX: Texas A\&M University Press.

Buchanan, J. M., \& Tullock, G. (1962). The Calculus of Consent. Ann Arbor: University of Michigan Press.

Cane, P. (2011). Administrative Law (5th ed.). Oxford: Oxford University Press.

Cass, R. A., Diver, C. S., Beerman, J. M., \& Freeman, J. (2011). Administrative law: cases and materials (6th ed.). New York: Wolters Kluwer Law \& Business

Cialdini, R. B. (1998). Influence: The Psychology of Persuasion. Perennial Currents.

Cohen, T. R., Panter, A. T., \& Turan, N. (2012). Current Directions in Psychological Science. CDPS, 21(5), 355-359.

Denhardt, R. B., \& Denhardt, V. J. (2000). The New Public Service: Serving Rather than Steering. Public Administration Review, 60(6), 549-559. http://dx.doi.org/10.1111/0033-3352.00117 
Disraeli, B. (1907). Sybil; or The two nations. London: Longmans, Green.

Durkheim, E. (1984). The Division of Labor in Society. Trans. W. D. Halls. New York: Free Press.

Durkheim, E. (1992). Professional Ethics and Civic Morals. Trans. Cornelia Brookfield. London: Routledge.

Dworkin, R. (1978). Taking Rights Seriously. Cambridge: Harvard University Press.

Dworkin, R. (2006). Justice in Robes. London: Harvard University Press.

Dworkin, R. (2011). Justice for Hedgehogs. London: Harvard University Press.

Etzioni, A. (1967). Mixed-Scanning: A “Third” Approach to Decision Making. Public Administration Review, 27(5), 385-392. http://dx.doi.org/10.2307/973394

Etzioni, A. (2004). The Common Good. Malden: Polity.

European Commission, The European Qualifications Framework (EQF). Retrieved from http://ec.europa.eu/education/lifelong-learning-policy/eqf_en.htm

Farmer, D. J. (2010). Public Administration in Perspective: Theory and Practice through Multiple Lenses. New York: M.E. Sharpe.

Fast, N. J. (2011). The destructive nature of power without status. Journal of Experimental Social Psychology.

http://dx.doi.org/10.1016/j.jesp.2011.07.013

Foucault, M. (2010). The Order of Things. London: Routledge.

Frederickson, H. G. (1980). New Public Administration. University, AL: University of Alabama Press.

Frederickson, H. G. (1996). Comparing Government Movement with the New Public Administration. Public Administration Review, 56(3), 262-270. http://dx.doi.org/10.2307/976450

Fredericson, H. G. (2010). Social Equity and Public Administration. Armonk: M. E. Sharpe.

Frugoni, C. (1988). Pietro and Ambrogio Lorenzetti. Florence: Scala Books.

Fukuyama, F. (2006). America at the Crossroads: Democracy, Power, and the Neoconservative Legacy. New Haven, CT: Yale University Press.

Fukuyama, F. (2013). Commentary: What is Governance? Governance. http://dx.doi.org/10.1111/gove.12035

Giddens, A. (1984). The Constitution of Society: Outline of a Theory of Structuration. Berkeley and Los Angeles: University of California Press.

Glasser, W. (1994). Kontrolna teorija. Ljubljana: Taxus.

Goodnow, J. F. (1900). Politics and Administration. New York: The MacMillan Company.

Hamilton, J. (1788). The executive branch needs energy for good governance. The Federalist, No. 70, The Executive Department Further Considered. March 18, 1788.

Kelly, G. M., \& Mulgan, G. (2002). Creating Public Value: An analytical framework for public service reform. London: Prime Minister's Strategy Unit, Cabinet Office.

Lammers, J., \& Stapel, D. A. (2009). How power influences moral thinking. Journal of Personality and Social Psychology, 97(2), 279-289. http://dx.doi.org/10.1037/a0015437

Lenoble, J., \& Maesschalck, M. (2010). Democracy, Law and Governance. Burlington: Ashgate.

Lindblom, C. E. (1959). The science of muddling through. Public Administration Review, 19, 79-88. http://dx.doi.org/10.2307/973677

Long-Green, A. (2009). Challenges and Effective Practices in Managing the Multisector Workforce. In H. S. Sistare, M. H. Shiplett, \& T. F. Buss (Eds.), Innovations in Human Resource Management Getting the Public's Work Done in the 21st Century. Armonk: M.E. Sharpe.

Lukacs, J. (2005). Democracy and Populism: Fear and Hatred. New Haven, CT: Yale University Press.

Lynch, T. D., \& Lynch, C. E. (2006). Twenty-First-Century Philosophy and Public Administration: Refocusing the Lens. In T. D. Lynch, \& P. L. Cruise (Eds), Handbook of Organization Theory and Management: The Philosophical Approach. New York: Taylor \& Francis.

Matthews, P. (2004). The MBTI is a flawed measure of personality. Retrieved from http://www.bmj.com/rapid-response/2011/10/30/mbti-flawed-measure-personality 
Meier, K. J. (1997). Bureaucracy and Democracy: The Case for More Bureaucracy and Less Democracy. Public Administration Review, 57(3), 193-199. http://dx.doi.org/10.2307/976648

Merton, R. K. (1968). Social Theory and Social Structure. New York: Free Press.

Miles, R. E. Jr. (1978). The Origin and Meaning of Mile's Law. Public Administration Review, 38(5), 399-403.

Mises, L. (1946). Bureaucracy. New Haven: Yale University Press.

Moore, M., \& Sanjeev, K. (2004). On Creating Public Value: What Business Might Learn from Government about Strategic Management. Corporate Social Responsibility Initiative Working Paper No. 3. Cambridge, MA: John F. Kennedy School of Government, Harvard University.

Myers, I., \& Myers, P. B. (1980, 1995). Gifts Differing: Understanding Personality Type. Mountain View, CA: Davies-Black Publishing.

Niskanen, W. (1994). Bureaucracy and Public Economics. New York: Edward Elgar.

Norman, R. (2001). Letting and making managers manage: the effect of control systems on management action in New Zealand's central government. International Public Management Journal, 4, 65-89. http://dx.doi.org/10.1016/S1096-7494(01)00043-5

Northcote, S. H., \& Trevelyan, C. E. (1854). Report on the organization of the permanent civil service together with a letter of the Rev. B. Jowett. London: HMSO.

O'Toole, J. B. (2006). The Ideal of Public Service Reflections on the higher civil service in Britain. London: Routledge.

Osborne, D., \& Plastrik, P. (1998). Banishing Bureaucracy: The Five Strategies for Reinventing Government. New York: A Plume Book.

Osborne, D., \& Plastrik P. (2000). The Reinventor's Fieldbook. Tools for Transforming Your Government. San Francisco: Jossey Bass.

Osborne, S. P. (Ed.). (2010). The New Public Governance: Emerging perspectives on the theory and practice of public governance. London: Routledge.

Overeem, P. (2008). Regime Change for Regime Values? Applying the Constitutionalist Approach to Public Administration Outside America. Paper prepared for the Research Workshop 'Public Values and Public Interest', Copenhagen, May 28-31.

Pegis, A. C. (Ed.). (1945). Basic Writings of Saint Thomas Aquinas. York: Random House.

Perry, J. J., \& Hondeghem, A. (2008). Motivation in Public Management. New York: Oxford University Press.

Peters, B. G. (2010). Meta-Governance and Public Management. In S. P. Osborne (Ed.), The New Public Governance. London: Routledge.

Piff, P. K., Stancato, D. M., Côté, S., Mendoza-Denton, R., \& Keltner, D. (2012). Higher Social Class Predicts Increased Unethical Behavior. Proceedings of the National Academy of Sciences, 109(11), 4086-91. http://dx.doi.org/10.1073/pnas.1118373109

Pittenger, D. J. (1993). Measuring the MBTI...And Coming Up Short. Journal of Career Planning and Employment, 54(1), 48-52.

Pollitt, C. (2003). The Essential Public Manager. Philadelphia: Open University Press.

Pollit, C. (2012). 30 years of public management reforms: Has there been a pattern? Retrieved from http://blogs.worldbank.org/governance/30-years-of-public-management-reforms-has-there-been-a-pattern.

Pollitt, C., \& Bouckaert, G. (2011). Public Management Reform A Comparative Analysis-New Public Management, Governance, and the Neo-Weberian State (3th ed.). Oxford: Oxford University Press.

President's Commission on Federal Ethics Law Reform. (1989). To serve with honor: report and recommendations to the President. Washington, D.C: United States.

Recommendation of the European Parliament and of the Council of 23 April 2008 on the establishment of the European Qualifications Framework for lifelong learning. OJ, 2008/C 111/01.

Rohr, A. J. (1989). Ethics for Bureaucrats: An Essay on Law and Values (2nd ed.). New York: Marcel Dekker.

Rohr, J. A. (1998). Public Service, Ethics, and Constitutional Practice. Kansas: University Press of Kansas. 
Rothstein, B. (2000). Trust, Social Dilemmas and Collective Memories. Journal of Theoretical Politics, 12, 477-501. http://dx.doi.org/10.1177/0951692800012004007

Rowley, C. K. (Ed.). (1987). Democracy and Public Choice. Oxford: Basil Blackwell.

Rutgers, M. R., \& van der Meer, H. (2010). The Origins and Restriction of Efficiency in Public Administration: Regaining Efficiency as the Core Value of Public Administration. Administration \& Society, 42, 755-779. http://dx.doi.org/10.1177/0095399710378990

Sartre, J. P. (1981). Saint Genet: Comedien Et Martyr. Ljubljana: Cankarjeva založba.

Sewell, W. (1992). A Theory of Structure: Duality, Agency, and Transformation. American Journal of Sociology, 98(1), 1-29.

Simon, A. H. (2000) [1945]. Administrative Behaviour. New York: The Free Press.

Sistare, H. S., Shiplett, M. H., \& Buss T. F. (Eds.). (2009). Innovations in Human Resource Management Getting the Public's Work Done in the 21st Century. Armonk: M. E. Sharpe.

Terry, D. L. (2005). The Thinning of Administrative Institutions in the Hollow State. Administration \& Society, 37, 426-444. http://dx.doi.org/10.1177/0095399705277136

Teubner, G. (1988). Hypercycle in Law and Organization: The Relationship Between Self-Observation, Self-Constitution, and Autopoiesis. In A. Febrajo (Ed.), European Yearbook in the Sociology of Law. Milan: Giuffre Publisher.

The EU 15 project. (2013). Better Regulation in Europe. Retrieved from http://www.oecd.org/gov/regref/eu15

Unger, R. M. (2004). False Necessity. New York: Verso.

United Nations E-Government Survey. (2010). New York: UN.

Wainwright, H., \& Little, M. (2009). Public Service Reform... But Not As We Know It! Hove: Picnic Publishing.

Waldo, D. (1948). The Administrative State. New York: The Roland Press Company.

Weber, M. (1978). Economy and Society. In G. Roth, \& C. Wittich (Eds.). Berkeley: University of California Press.

Wilson, W. (1887). The Study of Administration. Political Science Quarterly, 2(2), 197-222. http://dx.doi.org/10.2307/2139277

Woolf, R. (2004). Cicero: On Moral Ends. In J. Annas (Ed.). trans. Raphael Woolf. Cambridge: Cambridge University Press.

\section{Notes}

Note 1. The EU 15 project (Better Regulation in Europe) has put among the most important general perspectives of the 15 states 'a concern that the number of regulations is increasing ... better regulation rather than deregulation is the key concept ... multilevel governance has yet to take off as an integrated policy ... public governance traditions, cultural and geographical differences matter' (2013).

Note 2. Remember on Tacit's Corruptissima re publica plurimae leges (tr. as "the more numerous the laws, the more corrupt the government").

Note 3. This notion is shown e.g. in the notions of good administration, good governance, sound governance, co-governance. Its most famous painting is probably Lorenzetti's Allegory of the Good Government (1337-39), fresco in the Palazzo Pubblico, Siena (Frugoni, 1988, p. 37).

Note 4. Pollitt and Bouckaert speak about the public management reform as the deliberate changes to the structures and processes of public sector organizations with the objective of getting them (in some sense) to run better' (2011, p. 2). Within entire comparative and deliberate perspective - organisations should run "better"?

Note 5. Lat. officium, "translated as "appropriate action" in technical contexts, in particular those relating to Stoic ethical theory. The word is Cicero's translation of the Stoic Greek term kathékon, literally "appropriate (thing)", and is used to describe any action which may be rationally justified' (Woolf, 2004, p. xxxviii).

Note 6 . Weber's rational type of authority on which the claims of legitimacy rest is based 'on a belief in the legality of enacted rules and the right of those elevated to authority under such rules to issue commands' (Weber, 1978, p. 215). 
Note 7. A fundamental principle of administration, which follows almost immediately from the rational character of good administration, is that among several alternatives involving the same expenditure the one should always be selected, which leads to the greatest accomplishment of administrative objectives [...] since this principle of efficiency is characteristic of any activity that attempts rationally to maximize the attainment of certain ends with the use of scarce means: it is as characteristic of economic theory as it is of administrative theory. The "administrative man" takes his place alongside the classical "economic man" (Simon, 2000, p. 45).

Note 8 . While general theories about the way government processes operate may provide a useful starting place, those who seek to explain administrative origins must remain sensitive to the irreducible complexity of a messy reality (Cass et al., 2011, p. 10).

Note 9. The public servants have been in the past decades seen as the "self-interested decision makers a la public choice style" (Buchanan and Gordon, 1962; Niskanen, 1974; Rowley, 1987), or as the "legal, impartial implementers of decisions" a la public interest style, but not as de facto representatives of the public. Selfishness and/or impartial, impersonal stance do not go hand in hand with desire to do good; public servants not only follow political decisions, but also choose or recommend one alternative over the other, i.e. give predispositions of when, why, with what, to whom and how to achieve a public goal. We are talking about the responsible use of administrative discretion that cannot be in advance put in the law. With technological innovations and our needs for mutual cooperation to achieve more and more (global and/or public) goals, we are also more and more in a state of flux.

Note 10. Cognitum est in cognoscente secundum modum cognoscentis ("A known object is in the knowing mind according to the manner of the knower'; Pegis, 1945, p. 817).

Note 11. After 30 years of public management reforms Pollit gives some lessons: ' 1 . Big models, such as NPM or 'good governance' or 'partnership working', often do not take one very far. 2. The whole idea that there is one model or set of principles that can or should be applied everywhere is suspect. 3. Task differences really do matter. 4. PMR [public management reform] is usually saturated with vested interests, including those of the consultants/advisors, and the existing public service staff. 5. Successful PMR is frequently an iterative exercise, over considerable periods of time. 6. It does work sometimes!" (2012).

Note 12. See e.g. Foucalt's (2010, pp. 19-28) the four similitudes (convenientia, aemulatio, analogy and sympathy) or Althusser's (1970, pp. 186-189) three types of effectivity (the mechanistic or Cartesian system [transitive and analytical effectivity], the Leibnitzian concept of expression [the whole is reducible to an inner essence] and that of structural causality [an object is to designate the mode of presence of the structure in its effects]).

Note 13. The idea of the state is the conscience of administration (1887, p. 201). Michel Debre, the founder of the Ecole National d'Administration, had once said that the purpose of that prestigious institution was to instill in its students le sens de l'Etat ("a sense of the state") (Rohr, 1998, p. x).

Note 14. The thin institutions are weak, because they lack capacity to be good administration, i.e. to maintain the people's confidence in government (Terry, 2005).

Note 15. The notions of public value, good administration, administrative justice, governance, good governance, sound governance, global governance, e-governance as well as the governance of e-government, network-centric governance and the recent meta-governance (the notion of meta-governance is that a number of organizations and processes within the public sector have attained a substantial degree of autonomy - a condition often described as governance - and that there may be a need to impose some control over those components of governing [Peters, 2010, p. 37]).

Note 16. Kelly et al. summarise their approach by presenting three principle sources of public value: high-quality services, outcomes that reflect public priorities, and trust.

Note 17. Our effort is not to abandon legal doctrine, but to infuse it with flesh and blood-to orient the course around what is peculiar to the formation and operation of administrative agencies, to place administrative law issues in the political and social context (Cass et al., 2011, p. xxvi). The administration is having two masters-politics and law-both of which must serve. Law's demands on the administration may conflict not only with those of its political masters but also with the imperatives of managerialism, which reflect the 'master-servant' relationship between the elected executive and the appointed administration (Cane, 2011, p. 348). Although awareness of many sides and many layers that can influence the PA is welcomed, the similar is influence of public servants themselves. Good administration and administrative justice in administrative law point to the legal principle of good administration, even to the right (see the Article 41 of the EU Charter of human rights) that must 
be in its core open for the innovative and different content. They too - along of their new emphasis on today's complexity - use the words of "good" and "justice" which are present within the law from its beginnings.

Note 18. Especially by the notions of decentralisation, centralisation, de-concentration, hierarchy, governance, hollowing out, lowering, thinning of the state departments, net-centric government etc.

Note 19. Management (in both public and private sectors) is a significantly context-dependent craft - that individual techniques and processes, which work well in one context, may fail miserably in another. So it is vital to think about both the instrument or practice, and the context into which it is to be placed (Pollitt, 2003, p. xii).

Note 20. The controller grows with the system, and... the controller evolved with the system too. For these reasons it is best to ask how a system under control is aware of itself and its own states, rather than to ask how a controller can become aware of the state of the system (Beer, 1972, p. 35).

Note 21. Once the public official loses his or her ethical distinctiveness, there is no longer any reason for the public to regard the sector named after it as deserving of any particular respect, effort or loyalty (Pollitt, 2003, p. 24).

Note 22. Also lawyers can start with Ulpian's mixture of ethical and moral elements: honeste vivere, alterum non laedere, suum cuique tribuere (to live honestly, not to injure another, and to give to each one that which belongs to him).

Note 23. Error-correcting feedbacks are necessarily negative if any deviation from a given norm is counted as an absolute value; it is positive discrepancy...the total system is dominated, not by the forward network, but by the feedback network (Beer, 1972, pp. 49-50).

Note 24. What is striking is that here efficiency is applied to persons or a body of persons rather than to processes or organizations. It is primarily a characteristic or capacity of an individual or group of individuals. Being efficient concerns character, ability, and experience; the best and brightest, with the highest qualifications; as well as the able and energetic (Rutgers and van der Meer, 2010, p. 766).

Note 25. It is believed that the real political institutions of different peoples at the same stage of intelligence and morality will show a great similarity, even where the external forms of government appear very different. ... After all man is man everywhere and in all times ... have ultimately the same ends, and must adopt in a general way the same methods for their satisfaction (Goodnow, 1900, p. 7).

Note 26. Is not the basis of the science of public administration to 'get back to the formal governmental organization and examine the real political life of the people ... to look beyond the provisions of positive law (Goodnow, 1900, p. 1)?

Note 27. It is the culture that is self-referential or autopoietic (Teubner, 1988), self-demanding, irrelevant of the cause that they're after: '[r]einventing government is about creating public organizations that constantly look for ways to become more efficient. ... It is about creating public organizations and systems that habitually innovate, that continually improve their quality, without having to be pushed from outside. It is about creating a public sector that has a built-in drive to improve-what some call a "self-renewing system" ' [emphasis added] (Osborne and Plastrik, 1998, p. 14; 2000, p. 4).

Note 28. The quality of the administrative justice system will depend upon the behaviours and attitudes of those who work within it. Administrative justice is not simply a matter for ombudsmen, tribunals or courts. It begins in your organization when you gather information and evidence, exercise discretion and apply legislation and rules to reach decisions, which affect people or other organizations (AJCT, 2010, p. 11, 15).

Note 29. E-government is built for speed and for managing complexity ... at the same time it should not be regarded as a technological 'fix'. E-government especially, of all the e-buzzwords, can only be as good as the 'dynamic interactive capabilities' of the policy makers who apply their principles and models to its design, together with those of the people who construct and operate its systems (United Nations E-Government Survey, 2010, p. 41).

Note 30 . He argues that the central activity of public managers is the creation of public value: '[ $t]$ he strategic problem for public managers thus come to be: imagine and articulate a vision of public value that can command legitimacy and support, and is operationally doable in the domain for which you have responsibility' (Moore and Sanjeev, 2004, p. 9).

Note 31. The NPA has added to the classic public administration's efficiency and economy the question of social equity: 'to say that a service may be well managed and that a service may be efficient and economical, still begs these questions: Well managed for whom? Efficient for whom? Economical for whom? Traditional public administration assumed a convenient oneness to the public' (Frederickson, 1980). 
Note 32. Fast et al. (2011) e.g. warn on the destructive nature of power without status: 'the experience of having power without status ... may be a catalyst for producing demeaning behaviors that can destroy relationships and impede goodwill' (ibid, p. 3). This experience can be merged with the idea of Lammers and Stapel (2009) who under the five studies concluded that high power increases the use of rule-based (deontological) moral thinking styles, whereas low power increases reliance on outcome-based (consequentialist) moral thinking. For this reason, the powerful are also more inclined to stick to the rules, irrespective of whether this has positive or negative effects, whereas the powerless are more inclined to make exceptions. Piff et al.'s (2012) claim, that 'individuals from "upper-class" backgrounds were more likely to behave unethically than "lower-class" individuals', is similar already to Disraeli's view on members of upper class. This kind of (un)selfish behaviour can be comparable with guilt proneness: people who score high on measures of guilt proneness (compared to low scorers) make fewer unethical business decisions, commit fewer delinquent behaviors, and behave more honestly when making economic decisions. In the workplace, guilt-prone employees are less likely to engage in counterproductive behaviors that harm their organization (Cohen et al., 2012). Although these conclusions in one way or another connect good behaviour with unselfish power merged with (the higher the better) high formal status, they disregard the fact that we can be or do good without power or status (e.g. rescuing a human being by putting in danger our own life, saints and all the people that avoid doing harm to others), that we can do wrongs even with the best intentions, and that rules should have a positive effect - if we want legal state, sometimes even regardless for our future (whistleblowing). These conclusions can be put in one common denominator: they all connect behaviour with good intentions and the latter cannot be viewed as problems or consequences, but as issues or principles that need to resolve the conflict of values.

Note 33. "Efficient for what?" Is not efficiency for efficiency's sake meaningless? Is efficiency not necessarily measured in terms of other values? ... We hold that efficiency cannot itself be a "value." Rather, it operates in the interstices of a value system; it prescribes relationships (ratios or proportions) among parts of the value system; it receives its "moral content" by syntax, by absorption. Things are not simply "efficient" or "inefficient." They are efficient or inefficient for given purposes, and efficiency for one purpose may mean inefficiency for another (Waldo, 1948, p. 202).

Note 34. It started in 1948 with the work of Duncan Black, On the Rationale of Group Decision-making (1948).

Note 35. We should have in mind that state as legal entity is only a fiction: for Durkheim state 'is a group of officials sui generis, within which representations and acts of volition involving the collectivity are worked out, although they are not the product of collectivity [...] the State is a special organ whose responsibility is to work out certain representations which hold good for the collectivity [... but] it is others, the administrative bodies of all kinds, who are in charge of carrying out the changes' (Durkheim, 1992).

Note 36. See Physics. http://classics.mit.edu/Aristotle/physics.2.ii.html\#187. In the third chapter of the second book of Physics he thinks that it is necessary to use four different explanatory principles according to the question about causes for the existence of things. Each thing (animal, plant...) has four causes: material cause (the content causa materialis), formal cause (form - causa formalis), motion ground (a force that causes a merger of content and form - causa efficiens) and the final cause (goal - causa finalis). Explanation of all four causes explains entire importance and reality of things. He declared a substantial notion of the human's efficiency as the moving cause that binds the material and formal cause together in the name of the final cause - its purpose.

Note 37. Laws, oaths, and policies can be assessed as to their efficiency in arriving at the intended purposes, ends, or final causes. In this sense, efficiency is the force or ability to arrive at desired changes or effects, and as such is not just a synonym for effects, efficacy, or (the more modern term) effectivity (Rutgers and van der Meer, 2010, pp. 766-767, emphasis added).

Note 38. The executive branch needs energy for good governance (1788).

Note 39. Authority [...] is established to ensure respect for beliefs, traditions and collective practices, to defend the common consciousness [and vice versa] the energy immanent within the consciousness is communicated to that authority, just as affinities of ideas are transmitted to the words they represent (1984, p. 42).

Note 40 . The need for an administrative theory resides in the fact that there are practical limits to human rationality, and that these limits are not static, but depend upon the organizational environment in which the individual's decision takes place. The task of administration is so to design this environment that the individual will approach as close as practicable to rationality (judge in terms of the organization's goals) in his decisions (ibid; 322).

Note 41. He suggests - based on four approaches (1. procedural measures, such as the Weberian criteria of bureaucratic modernity; 2. capacity measures, which include both resources and degree of professionalization; 3 . 
output measures; and 4. measures of bureaucratic autonomy) - a two-dimensional framework of using capacity and autonomy as a measure of executive branch quality. While he proposes proportionality between capacity and autonomy ('the higher the capacity of bureaucracy, then, the more autonomy one would grant them' [2013, p. 15]), he at the same time recognises 'the existing quantitative measures [as] woefully inadequate' (ibid, p. 17).

Note 42. The main point to emerge from recent history is much the same as in the Great Depression: no amount of good practice by e-government or other means can withstand the consequences of a beginning from a false set of assumptions (United Nations E-Government Survey, 2010, p. 40).

Note 43. Nobody calls himself a bureaucrat or his own methods of management bureaucratic (Mises, 1946, p. 1).

Note 44. This vehement indictment of bureaucracy is, by and large, an adequate although emotional description of present-day trends ... but it misses the point as it makes bureaucracy and the bureaucrats responsible for an evolution the causes of which must be sought for elsewhere. Bureaucracy is but a consequence and a symptom of things and changes much more deeply rooted. It is true that the officeholders are no longer the servants of the citizenry, but irresponsible and arbitrary masters and tyrants. But this is not the fault of bureaucracy. It is the outcome of the new system of government, which restricts the individual's freedom to manage his own affairs and assigns more and more tasks to the government. The culprit is not the bureaucrat but the political system. And the sovereign people are still free to discard this system (Mises, 1946, pp. 3-4, 9).

Note 45. If we are inclined to believe that people are self-interest maximizing in all that they do, then we are likely to construct incentive systems that take advantage of this human instinct and simultaneously protect against dysfunctions associated with it. In contrast, if public servants are general altruists, then we will be inclined to rely on them to do good at all times (Perry and Hondeghem, 2008, p. 8). Social psychologists and economists who draw on psychology have documented how control systems designed to reward self-interest crowd out intrinsic motivations. Deci et al.'s (1999) meta-analysis of experimental data shows that various forms of financial incentives, including performance incentives, reduce intrinsic motivation. Frey (1997) and Gneezy and Rustichini (2000) find crowding-out effects on forms of civic duty (Moynihan, 2008, p. 250).

Note 46. Merton describes 'the self-fulfilling prophecy, that is, in the beginning, a false definition of the situation evoking a new behaviour which makes the original false conception come "true". This specious validity of the self-fulfilling prophecy perpetuates a reign of error. For the prophet will cite the actual course of events as proof that he was right from the very beginning' (1968, p. 477).

Note 47. No ultimative distinction can be made between legal and moral standards, as positivism insists (Dworkin, 1978, p. 46). A proposition of law is true, if it flows from principles of personal and political morality that provide the best interpretation of the other propositions of law generally treated as true in contemporary legal practice (Dworkin, 2006, p. 14).

Note 48. Learning outcomes means statements of what a learner knows, understands and is able to do on completion of a learning process, which are defined in terms of knowledge, skills and competence. Knowledge means the outcome of the assimilation of information through learning. Knowledge is the body of facts, principles, theories and practices that is related to a field of work or study ... knowledge is described as theoretical and/or factual; skills mean the ability to apply knowledge and use know-how to complete tasks and solve problems ... skills are described as cognitive (involving the use of logical, intuitive and creative thinking) or practical (involving manual dexterity and the use of methods, materials, tools and instruments); competence means the proven ability to use knowledge, skills and personal, social and/or methodological abilities, in work or study situations and in professional and personal development ... competence is described in terms of responsibility and autonomy (Recommendation, 2008).

Note 49. From the level 1, where competence of a person is to work or study under direct supervision in a structured

context, up to the level 8, where the person is expected to demonstrate substantial authority, innovation, autonomy, scholarly and professional integrity and sustained commitment to the development of new ideas or processes at the forefront of work or study contexts including research (ibid).

Note 50. This pluralistic and all-encompassing process is very similar to decisions of a driver who drives on an unknown road and flexibly - according to his/her knowledge and other abilities - accommodates his/her actions to conditions on a road.

Note 51. It hasn't been my aim to tell people what to think...I have tried, rather, to tell them how to think-specifically, of course, about public administration (Waldo in Brown, 1986, p. 164). 
Note 52. We can find this concept in biology, within the concept of autopoeisis; that describes living organism as "self generating". It is also present in Zen where the state of non-contradiction is denied. In Zen "the thing" and "not the thing" are always together (like the concept of yin-yang).

Note 53. According to the Assessment and Teaching of 21st-Century Skills (ATC21S is a research project that proposes ways of assessing 21 st-century skills and encourages teaching and adopting those skills in the classroom) that stared with a group of more than 250 researchers across 60 institutions worldwide, categorized 21 st-century skills internationally into four broad categories (1) Ways of thinking: Creativity, critical thinking, problem-solving, decision-making and learning; (2) Ways of working: Communication and collaboration; (3) Tools for working: Information and communications technology (ICT) and information literacy and (4) Skills for living in the world: Citizenship, life and career, and personal and social responsibility (ATC21S, 2013).

\section{Copyrights}

Copyright for this article is retained by the author(s), with first publication rights granted to the journal.

This is an open-access article distributed under the terms and conditions of the Creative Commons Attribution license (http://creativecommons.org/licenses/by/3.0/). 